\title{
Full remission and relapse of obsessive-compulsive symptoms after cognitive-behavioral group therapy: a two-year follow-up
}

\section{Remissão completa e recaídas dos sintomas obsessivo- compulsivos depois da terapia cognitivo-comportamental em grupo: dois anos de acompanhamento}

\author{
Daniela Tusi Braga, ${ }^{1}$ Gisele Gus Manfro, ${ }^{2}$ Kátia Niederauer, ${ }^{1}$ Aristides Volpato Cordioli ${ }^{2}$ \\ ${ }^{1}$ Universidade Federal do Rio Grande do Sul (UFRGS), Porto Alegre, RS, Brazil \\ ${ }^{2}$ Department of Psychiatry, Anxiety Disorders Program, Hospital de Clínicas, Universidade Federal do Rio Grande do Sul (UFRGS), \\ Porto Alegre, RS, Brazil
}

\begin{abstract}
Objective: The aim of this study was to assess whether the results obtained with 12 sessions of cognitive-behavioral group therapy with obsessive-compulsive patients were maintained after two years, and whether the degree of symptom remission was associated with relapse. Method: Forty-two patients were followed. The severity of symptoms was measured at the end of cognitive-behavioral group therapy and at 18 and 24 months of follow-up. The assessment scales used were the Yale-Brown Obsessive-Compulsive Scale, Clinical Global Impression, Beck Depression Inventory, and Beck Anxiety Inventory. Results: The reduction in symptom severity observed at the end of treatment was maintained during the two-year follow-up period ( $\mathrm{F}=57.881$; $\mathrm{p}<$ $0.001)$. At the end of the treatment, $9(21.4 \%)$ patients presented full remission, 22 (52.4\%) presented partial remission, and 11 (26.2\%) had unchanged scores in the Yale-Brown Obsessive-Compulsive Scale. After two years, 13 patients (31.0\%) presented full remission, 20 (47.6\%) had partial remission, and $9(21.4 \%)$ had unchanged Yale-Brown ObsessiveCompulsive Scalescores. The full remission of symptoms at the end of the treatment was a protective factor against relapse $\left(\chi^{2}=4,962 ; \mathrm{df}=1\right.$; $\mathrm{p}=0.026)$. Conclusion: Our findings underscore the importance of attaining full remission of obsessive-compulsive symptoms during treatment and the need for new therapeutic strategies to achieve this.
\end{abstract}

Descriptors: Obsessive-compulsive disorder; Cognitive therapy; Psychotherapy, group; Longitudinal studies; Recurrence

\section{Resumo}

Objetivo: Avaliar se os resultados obtidos com 12 sessôes de terapia cognitivocomportamental em grupo para pacientes com transtorno obsessivo-compulsivo foram mantidos depois de dois anos do final do tratamento e se o grau de remissão dos sintomas esteve associado às recaídas. Método: Quarenta e dois pacientes foram acompanhados. A gravidade dos sintomas foi avaliada no final da terapia cognitivo-comportamental em grupo, 18 e 24 meses após o término do tratamento. As escalas utilizadas para avaliação foram Yale-Brown ObsessiveCompulsive Scale, Clinical Global Impression, Beck Depression Inventory $e$ Beck Anxiety Inventory. Resultados: A redução da gravidade dos sintomas observada no final do tratamento foi mantida durante o periodo de dois anos de acompanhamento $(F=57,881 ; p<0,001)$. Ao final do tratamento, 9 $(21,4 \%)$ pacientes apresentaram remissão completa, $22(52,4 \%)$ remissão parciale 11 (26,2\%) não apresentaram mudança na Yale-Brown ObsessiveCompulsive Scale. Dois anos depois, 13 pacientes (31,0\%) apresentaram remissão completa dos sintomas, $20(47,6 \%)$ apresentaram remissäo parcial, e 9 $(21,4 \%)$ não apresentaram mudança na Yale-Brown Obsessive-Compulsive Scale. A remissão completa dos sintomas ao final do tratamento foi protetora contra recaidas $\left(\chi^{2}=4,962 ; d f=1 ; p=0,026\right)$. Conclusão: Nossos achados apontam para a importância da obtenção da remissão completa dos sintomas obsessivo-compulsivos e para a necessidade de novas estratégias terapêuticas que tenham como meta atingir tal objetivo.

Descritores: Transtorno obsessivo-compulsivo; Terapia cognitiva; Psicoterapia de grupo; Estudos longitudinais; Recidiva

\section{Introduction}

Achieving full symptom remission has increasingly become the main goal of any treatment for psychiatric disorders. The presence of residual symptoms in depression, ${ }^{1,2}$ panic disorder, ${ }^{3}$ generalized anxiety disorder, and social phobia ${ }^{4}$ has been associated with a higher risk of relapse and chronicity. In the context of the treatment of obsessive-compulsive disorder (OCD), however,
Submitted: April 14, 2009

Accepted: December 3, 2009

\section{Correspondence}

Daniela Tusi Braga

Department of Psychiatry, Universidade Federal do Rio Grande do Sul Rua Ramiro Barcelos, 2350, sala 400N

90035-903, Porto Alegre, RS, Brazil

Phone: (+55 51) 3316-8294 Fax: (+55 51) 3316-8493

E-mail: dtbraga@gmail.com 
this association has not yet been properly addressed. ${ }^{5}$ Recent studies suggest that full remission should be the main goal in the treatment of OCD. ${ }^{6,7}$

In a two-year naturalistic follow-up study, Eisen et al. reported a probability of achieving full remission of obsessive-compulsive symptoms of $12 \% .^{8}$ Steketee et al. carried out two assessments, at one and five years of follow-up, and found a rate of $15 \%$ of full remission at the end of the first year and of $20 \%$ after five years. ${ }^{9}$ In a recent study, Catapano et al. evaluated the long-term course of OCD in patients treated with SSRIs and found that the cumulative probability of achieving full remission three years after treatment was of $38 \% .{ }^{10}$ On the other hand, the discontinuation of the treatment with anti-obsessive medication was associated with a relapse rate of $90 \%$ or more. ${ }^{11}$

The aim of this study was to investigate whether the results observed with cognitive-behavioral group therapy (CBGT) in OCD patients at the end of the treatment were maintained after two years. Moreover, the authors investigated whether full remission of obsessive-compulsive symptoms at the end of the treatment was associated with relapse within this period.

\section{Method}

\section{Study design and sample}

A longitudinal, naturalistic study was performed. A cohort of 42 patients was assessed 18 and 24 months after the end of 12 sessions of CBGT (three months after beginning treatment). The results of the 12-month follow-up have been reported elsewhere. ${ }^{7}$

The patients' selection and diagnosis procedures have been described in a previous study. ${ }^{7} \mathrm{~A}$ total of 44 patients completed a manual-based CBGT program as described in Cordioli et al., ${ }^{12}$ and 42 of them were evaluated during a one-year follow-up period, between October 2000 and October 2001. ${ }^{7}$ New follow-up data were collected from the same 42 patients between October 2001 and November 2003 using the instruments described below.

The study protocol was approved by the Ethics Committee of the Hospital de Clínicas de Porto Alegre (HCPA), number 01375 , as reported in Braga et al. ${ }^{7}$ All patients signed an informed consent form.

Out of the 44 patients who completed the 12 weekly sessions, 42 were evaluated face-to-face during the follow-up period. Two patients were excluded: one was lost during follow-up and the other refused to participate in the study.

\section{Assessments}

The severity of obsessive-compulsive symptoms was measured using the Yale-Brown Obsessive-Compulsive Scale (Y-BOCS); ${ }^{13}$ the Clinical Global Impression (CGI) scale for assessing measure the severity of obsessive-compulsive symptoms. ${ }^{14}$ The participants also completed the Beck Depression Inventory (BDI) for assessing the severity of depression symptoms and the Beck Anxiety Inventory (BAI) for assessing the severity of anxiety symptoms. ${ }^{15}$ The scales were applied 18 and 24 months after the end of the treatment with CBGT by two independent trained evaluators who did not take part in the CBGT sessions.
Patients showing improvement after CBGT (reduction of $35 \%$ or more in Y-BOCS scores and CGI $\leq 2$ ) were evaluated in respect to the maintenance of therapeutic gains and relapse. Maintenance of therapeutic gains was defined as the absence of changes in Y-BOCS and CGI scores during the two-year followup period. Full remission was considered to be achieved when a reduction of $35 \%$ or more in Y-BOCS scores was observed immediately after CBGT and when Y-BOCS scores were below 8 and CGI scores below 2. Relapse was defined when patients showing improvement after CBGT presented an increase of 35\% or more in Y-BOCS scores and a CGI score higher than 1 during the follow-up period.

\section{Statistical analysis}

The maintenance of therapeutic gains was assessed by comparing the Y-BOCS and CGI scores at three different moments: end of the CBGT program and 18 and 24 months of follow-up. Comparisons were carried out using analysis of variance (ANOVA) for repeated measures. The chi-square test was used for dichotomous variables: full remission at the end of the treatment and relapse during the follow-up period. The Statistical Package for the Social Sciences (SPSS), version 12.0, was used to analyze data. The statistical significance level was set at $\mathrm{p}<0.05$.

\section{Results}

\section{Sociodemographic and clinical characteristics}

The sociodemographic and clinical characteristics of the sample are described in detail in Braga et al. (2005) and summarized below. Of the 42 patients followed, 26 (61.9\%) were female and the mean age was 36.8 years $(S D=13.2)$. The mean duration of illness was 21.5 years $(\mathrm{SD}=11.6)$ and the mean age at $\mathrm{OCD}$ onset was 14.8 years $(\mathrm{SD}=6.9)$. Before undergoing CBGT, $17(40.5 \%)$ patients had been on pharmacological treatment for a mean of 12 years. During the two-year follow-up period, 21 patients (50\%) sought for some kind of treatment: 16 maintained the use of antiobsessive drugs, and 5 started individual CBT or CBT associated with anti-obsessive drugs. The remaining 21 patients (50\%) did not undergo any treatment during the follow-up period.

\section{Maintenance of CBGT results during the follow- up period}

The group of patients presented a mean Y-BOCS score of 25.6 $(\mathrm{SD}=5.29)$ at baseline and of $13.2(\mathrm{SD}=7.42)$ at the end of the CBGT program. Two years later, the mean Y-BOCS score was $11.9(\mathrm{SD}=9.4)$. While 31 patients $(73.8 \%)$ were considered to have improved at the end of the treatment (reduction of $35 \%$ or more in Y-BOCS scores and CGI $\leq 2), 33$ patients (78.6\%) met the same criteria at the two-year follow-up assessment.

Repeated measures ANOVA showed significant differences in the mean Y-BOCS total scores and in the obsessions and compulsions subscales during follow-up $(\mathrm{F}=57.881$; $\mathrm{p}<0.001)$. The same was observed for the CGI scale $(\mathrm{F}=76.125$; $\mathrm{p}<0.001)$, and Bonferroni correction identified that the difference was the baseline for the other evaluation periods (12, 18 and 24 months 
Table 1 - Y-BOCS and CGI scores at week 12 (end of treatment) and at 18 and 24 months of follow-up (mean and standard deviation) $(\mathrm{N}=\mathbf{4 2})$

\begin{tabular}{lcccc}
\hline \multicolumn{1}{c}{ Scale } & $\begin{array}{c}\text { Baseline } \\
\text { Mean (sd) }\end{array}$ & $\begin{array}{c}\text { 12 weeks (end of treatment) } \\
\text { Mean (sd) }\end{array}$ & $\begin{array}{c}\text { 18 months } \\
\text { Mean (sd) }\end{array}$ & $\begin{array}{c}\text { 24 months } \\
\text { Mean (sd) }\end{array}$ \\
\hline Y-BOCS & $25.3(5.3)$ & $13.2(7.4)$ & $11.4(9.6)$ & $11.9(9.4)$ \\
Obses & $12.8(2.9)$ & $6.7(3.9)$ & $5.6(5.1)$ & $5.5(4.9)$ \\
Comp & $12.5(3.0)$ & $6.5(4.0)$ & $5.8(5.1)$ & $6.4(5.0)$ \\
CGI & $4.6(0.9)$ & $2.3(1.2)$ & $2.2(1.3)$ & $2.3(1.5)$ \\
\hline
\end{tabular}

${ }^{*}$ Analysis of variance for repeated measures (MANOVA), comparing the end of the treatment to 12, 18, and 24 months after treatment $(Y-$ BOCS: $F=57.881 ; p<0.001) . C G l:(F=76.125 ; p<0.001)$.

after the baseline), which indicates that the reduction in symptom severity observed at the end of the treatment with CBGT was maintained during the two-year follow-up period (Table 1).

Out of the 42 patients followed, $9(21 \%)$ presented full remission of the symptoms, $22(52.4 \%)$ had partial remission, and $11(26.2 \%)$ had no improvement at the end of the treatment. Two years later, $13(31 \%)$ patients presented full remission, 20 (47.6\%) had partial remission, and $9(21.4 \%)$ showed no improvement (Table 2).

During the follow-up period, we observed that the patients who achieved partial remission of symptoms changed their status more often between the categories of full remission and no improvement than the other two groups, which were more stable within their categories. Moreover, there were only two patients who changed from the status of no improvement to the group of full remission, and none of the patients belonging to the full remission group changed to the group of no improvement (Figure 1).

A statistically significant difference was observed in terms of relapse in the group that achieved partial remission when compared with the full remission group. None of the nine patients who achieved full remission at the end of CBGT presented relapse in the two-year follow-up; in contrast, 13 patients (41.9\%) out of the 22 who achieved partial remission at the end of CBGT presented relapse $\left(\chi^{2}=4,962 ; \mathrm{df}=1 ; \mathrm{p}=0,026\right)$.

\section{Discussion}

During two years, we followed 42 OCD patients who had previously attended 12 weekly sessions of CBGT. At the end of the program, 31 patients $(73.8 \%)$ were considered to have improved, whereas two years later this number increased to 33 (78.6\%). These results clearly show that the benefits of CBGT are maintained over a long period. This is in line with other studies; for example, Van Oppen et al. ${ }^{16}$ in a randomized controlled trial, observed the maintenance of clinical benefits in a five-year followup after cognitive therapy alone, in vivo exposure and response prevention (ERP) alone, and cognitive behavioral therapy (CBT) in combination with fluvoxamine. Additionally, Rufer et al. in a 7year follow-up after CBT in combination with either fluvoxamine or placebo, reported the maintenance of the results in $45 \%$ of the patients in the period. ${ }^{17}$

In our study, an increase was observed in the number of patients who met full remission criteria during the follow-up period, from 9 patients $(21.4 \%)$ immediately after treatment, to $13(31.0 \%)$ in the $24^{\text {th }}$ month, an increase of $44.4 \%$. The full remission rates were similar to those found in related studies, ${ }^{5,17}$ but a little higher than those reported in others. ${ }^{18,19}$ Some factors might explain these variable results. For example, the reduction of symptoms in OCD patients treated with SSRIs has been reported to be around $40-60 \%$, with a mean improvement of $20-40 \%,{ }^{18}$ which is lower than the rates obtained with CBT, usually between $50-75 \% .^{18,19}$ Moreover, differences in sample size, criteria and definitions for OCD full remission, and criteria for inclusion and exclusion of the patients, among other factors, may also have contributed to the different results.

Another interesting finding of the present study was a statistically significant difference in relapse rates during the 24-month period. None of the patients who had achieved full remission at the end of the treatment relapsed in the two-year period. On the other hand, 13 patients $(41.9 \%)$ out of the 22 who had achieved partial remission relapsed: 11 (85\%) during the first year, and 2 (15\%) during the second year. These results suggest that full remission was a protective factor against relapse - given that patients with partial remission were at high risk for relapse - and indicate that mental health professionals should give more attention to patients who achieve partial remission of symptoms, especially during the first year after treatment.

We also observed that patients who achieved partial remission

Table 2 - Number of patients with full remission, partial remission, and no improvement at the end of the treatment and at 18 and 24 months of follow-up ( $\mathrm{N}=\mathbf{4 2})$

\begin{tabular}{lccc}
\hline & End of treatment & $\mathbf{1 8}$ months & $\mathbf{2 4}$ months \\
& $\mathbf{n}(\%)$ & $\mathbf{n}(\%)$ & $1 \%(31.0)$ \\
\hline Full remission & $9(21.4)$ & $18(42.8)$ & $20(47.6)$ \\
Partial remission & $22(52.4)$ & $12(28.6)$ & $9(21.4)$ \\
No improvement & $11(26.2)$ & $12(28.6)$ & 9 \\
\hline
\end{tabular}




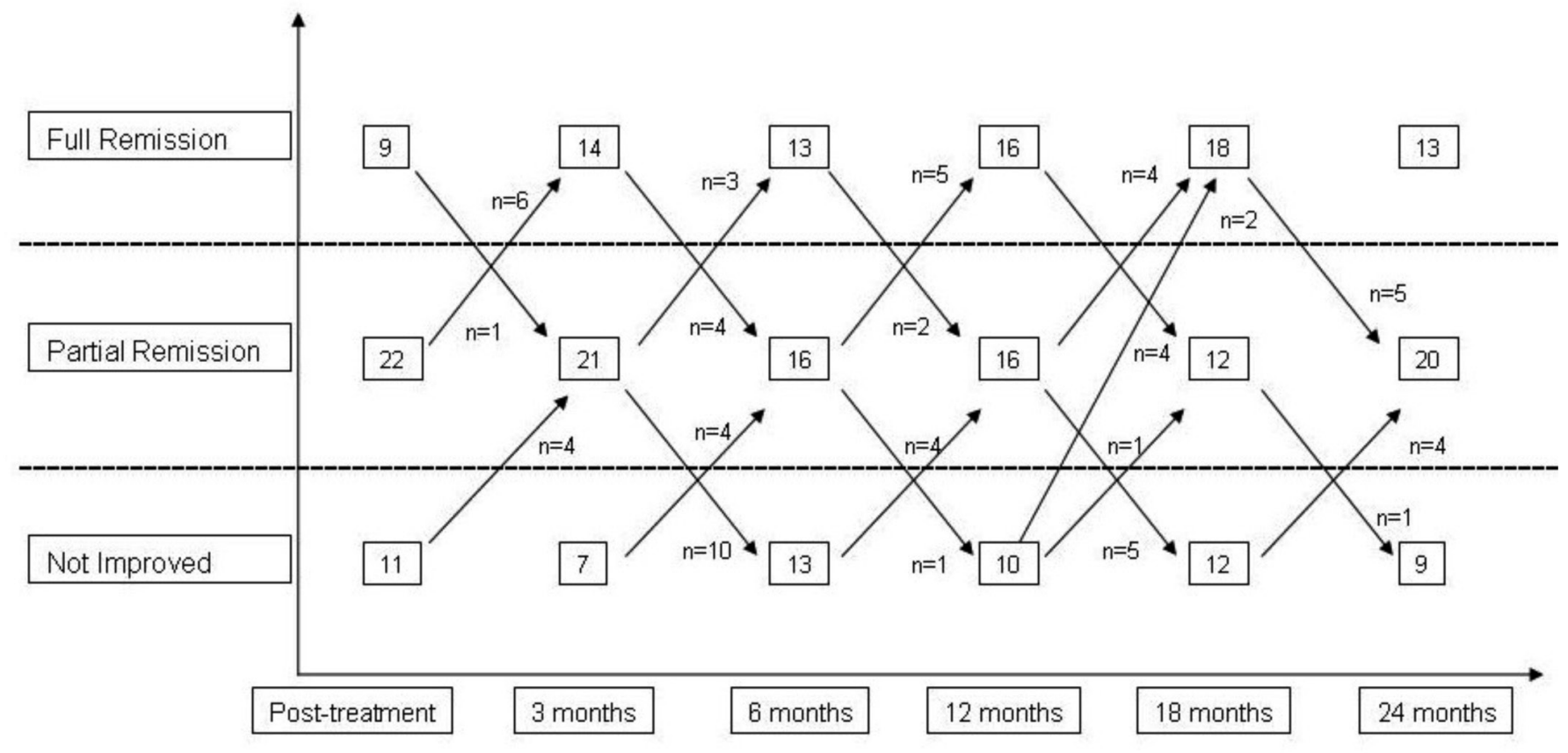

Figure 1 - Changes in the intensity of the symptoms over two years $(\mathrm{N}=42)$

with the use of pharmacological treatment had additional gains with CBT, with some patients even achieving full remission. ${ }^{20}$ Nevertheless, other studies have suggested that the association of ERP and anti-obsessive drugs is not a guarantee of increased effectiveness. ${ }^{16,21}$ As can be seen, the combined use of CBT and pharmacological treatment remains a controversial issue.

The limitations of our study were the small sample size, the absence of a control group, and the difficulty in controlling intervenient factors that are inherent to a naturalistic study. In addition, the disagreement regarding the criteria of full remission found in different studies represents another problem in the field, with a direct impact on the results. Further long-term followup studies involving a greater number of OCD patients and employing standardized criteria for partial and full remission are needed to confirm the findings of the present study and to allow for their generalization.

\section{Conclusion}

The results of this study emphasize the importance of the full remission of OCD symptoms at the end of the treatment for the prevention of relapse, suggesting a need for the development of new therapeutic strategies aimed at achieving this goal.

\section{Acknowledgements}

This study was supported by the Coordenação de Aperfeiçoamento de Ensino Superior (CAPES), Ministry of Education, Brazil.

\section{Disclosures}

\begin{tabular}{|c|c|c|c|c|c|c|c|}
\hline $\begin{array}{l}\text { Writing group } \\
\text { member }\end{array}$ & Employment & $\begin{array}{l}\text { Research } \\
\text { grant }^{1}\end{array}$ & $\begin{array}{l}\text { Other research grant or } \\
\text { medical continuous } \\
\text { education }^{2}\end{array}$ & $\begin{array}{l}\text { Speaker's } \\
\text { honoraria }\end{array}$ & $\begin{array}{c}\text { Ownership } \\
\text { interest }\end{array}$ & $\begin{array}{l}\text { Consultant/ } \\
\text { Advisory } \\
\text { board }\end{array}$ & Other $^{3}$ \\
\hline \multirow{2}{*}{$\begin{array}{l}\text { Daniela Tusi } \\
\text { Braga }\end{array}$} & HCPA & - & - & - & - & - & - \\
\hline & UFRGS & & & & & & \\
\hline \multirow{2}{*}{$\begin{array}{l}\text { Gisele Gus } \\
\text { Manfro }\end{array}$} & HCPA & - & - & - & - & - & - \\
\hline & UFRGS & & & & & & \\
\hline \multirow[t]{2}{*}{ Kátia Niederauer } & HCPA & - & - & - & - & - & - \\
\hline & UFRGS & & & & & & \\
\hline \multirow{2}{*}{$\begin{array}{l}\text { Aristides Volpato } \\
\text { Cordioli }\end{array}$} & HCPA & - & - & - & - & - & - \\
\hline & UFRGS & & & & & & \\
\hline \multicolumn{8}{|c|}{$\begin{array}{l}{ }^{*} \text { Modest } \\
{ }_{* \star}^{*} \text { Significant } \\
\text { *** Significant: Amounts given to the author's institution or to a colleague for research in which the author has participation, not directly to the author. } \\
\text { Note: HCPA = Hospital de Clínicas de Porto Alegre; UFRGS = Universidade Federal do Rio Grande do Sul. } \\
\text { For more information, see Instructions for authors. }\end{array}$} \\
\hline
\end{tabular}


References

1. Kennedy S. Full remission: a return to normal functioning. J Psychiatry Neurosci. 2002;27(4):233-4.

2. McIntyre RS, O'Donovan C. The human cost of not achieving full remission in depression. Can J Psychiatry. 2004;49(Suppl 1):10S-6S.

3. Kipper L, Blaya C, Wachleski C, Dornelles M, Salum GA, Heldt E, Manfro GG. Trauma and defense style as response predictors of pharmacological treatment in panic patients. Eur Psychiatry. 2007;22(2):87-1.

4. van Ameringen M, Allgulander C, Bandelow B, Greist JH, Hollander E, Montgomery SA, Nutt DJ, Okasha A, Pollack MH, Stein DJ, Swinson RP. World Council of Anxiety WCA recommendations for the long-term treatment of social phobia. CNS Spectr. 2003;8(8 Suppl 1):40-2.

5. Hollander E, Zohar J. Beyond refractory obsessions and anxiety states: toward remission. J Clin Psychiatry. 2004;65 Suppl 14:3-5.

6. Pallanti S, Hollander E, Goodman WK. A qualitative analysis of nonresponse: management of treatment-refractory obsessive-compulsive disorder. $J$ Clin Psychiatry. 2004;65 Suppl 14:6-10.

7. Braga DT, Cordioli AV, Niederauer K, Manfro GG. Cognitive-behavioral group therapy for obsessive-compulsive disorder: a 1-year follow-up. Acta Psychiatr Scand. 2005;112(3):180-6.

8. Eisen Jl, Goodman WK, Keller MB, Warshaw MG, Lyne MD, Luce $\mathrm{DD}$, Rasmussen SA. Patterns of remission and relapse in obsessivecompulsive disorder: a 2-year prospective study. J Clin Psychiatry. 1999;60(5):346-1.

9. Steketee G, Eisen J, Dyck I, Warshaw M, Rasmussen S. Predictors of course in obsessive-compulsive disorder. Psychiatry Res. 1999;89(3):229-8.

10. Catapano F, Perris F, Masella M, Rossano F, Cigliano M, Magliano L, Maj M. Obsessive-compulsive disorder: a 3-year prospective follow-up study of patients treated with serotonin reuptake inhibitors OCD follow-up study. J Psychiatr Res. 2006;40(6):502-10.

11. Pato, MT, Zohar, KM, Zohar, R. Return of symptoms after discontinuation of clorimipramine in patients with obsessive-compulsive disorder. $\mathrm{Am} \mathrm{J}$ Psychiatry. 1988;145(12):521-5.

12. Volpato Cordioli A, Heldt E, Braga Bochi D, Margis R, Basso Souza M, Tonello J, Gus Manfro G, Kapczinski F. Cognitive-behavioral group therapy in obsessive-compulsive disorder: a randomized clinical trial. Psychother Psychosom. 2003;72(4):211-6.

13. Goodman WK, Price LH, Rasmussen AS, Mazure C, Fleischmann RL, Hill CL, Heninger GR, Charney DS.The Yale-Brown ObsessiveCompulsive Scale: I development, use, and reliability. Arch Gen Psychiatry. 1989;46(11):1006-16.

14. Guy W. ECDEU assessment manual for psychopharmacology. Washington, DC: U.S. Department of Health, Education, and Welfare; 1976. p.218-2.

15. Cunha JA. Manual da versão em português das escalas de Beck. São Paulo (SP): Casa do Psicólogo; 2001.

16. van Oppen P, van Balkom AJ, de Haan E, van Dyck R. Cognitive therapy and exposure in vivo alone and in combination with fluvoxamine in obsessive-compulsive disorder: a 5 year follow-up. J Clin Psychiatry. 2005;66(11):1415-22.

17. Rufer M, Hand I, Alsleben H, Braatz A, Ortmann J, Katenkamp B, Fricke S, Peter $\mathrm{H}$. Long-term course and outcome of obsessive-compulsive patients after cognitive-behavioral therapy in combination with either fluvoxamine or placebo: a 7-year follow-up of a randomized double-blind trial. Eur Arch Psychiatry Clin Neurosci. 2005;255(2):121-8.

18. Sousa MB, Isolan LR, Oliveira RR, Manfro GG, Cordioli AV. A randomized clinical trial of cognitive-behavioral group therapy and sertraline in the treatment of obsessive-compulsive disorder. J Clin Psychiatry. 2006;67(7):1133-9.

19. Gava I, Barbui C, Aguglia E, Carlino D, Churchill R, De Vanna M, McGuire HF. Psychological treatments versus treatment as usual for obsessive compulsive disorder (OCD). Cochrane Database Syst Rev. 2007;18(2):CD005333.

20. Kapman M, Keijsers GP, Hoogduin CA, Verbraak MJ. Addition of CBT for OCD patients non-responding to fluoxetine. Acta Psychiatr Scand. 2002;106(4):314-9.

21. Foa EB, Liebowitz MR, Kozak MJ, Davies S, Campeas R, Franklin ME, Huppert JD, Kjernisted K, Rowan V, Schmidt AB, Simpson HB, Tu X. Randomized, placebo-controlled trial of exposure and ritual prevention, clomipramine, and their combination in the treatment of obsessivecompulsive disorder. Am J Psychiatry. 2005;162(1):151-1. 